\title{
Interrogating Sense of Place Through Tactical Urbanism of Women and Children in Kampung Kerapu, North Jakarta
}

\author{
Salsabila Andara S Alyani \\ Department of Architecture, Faculty of Engineering \\ Universitas Indonesia \\ Depok, Indonesia \\ salsabilandara@gmail.com
}

\author{
Herlily \\ Department of Architecture, Faculty of Engineering \\ Universitas Indonesia \\ Depok, Indonesia
}

\begin{abstract}
Sense of place is a concept within urban design. While sense of place is likely correlated with physical features of a city, previous studies have showed that sense of place is multidimensional, and involves factors, which are beyond mere physical attributes. Meanwhile, in the realm of formal urban planning, 'tactical urbanism' has emerged as a concept that is regarded as public's opportunistic response to their environment. As a bottom-up action, various aspects of interaction between public and features of a city is a mandatory issue in tactical urbanism. In this paper, we will explore the act of tactical urbanism within an urban neighborhood, Kampung Kerapu, North Jakarta, by particularly investigating the dwelling practice of women and children in their neighborhood. The streets of the kampung that lie between the river and the houses act as space that is used by the residents in their everyday spatial practices. We argue that this action defines another form of tactical urbanism as domestic spatial practice in an urban neighborhood. We will use emic approach to understand everyday domestic spatial practice of women and children in Kampung Kerapu. The analysis will show how certain adaptation of tactical urbanism is implemented. By examining everyday domestic spatial practice as tactical urbanism that creates different sense of place, this paper shows the role of women and children in the creation of sense of place through tactical urbanism in an urban neighborhood.
\end{abstract}

Keywords - Children, Sense of Place, Tactical Urbanism, Women

\section{INTRODUCTION}

Over the past few years, the act of tactical urbanism has grown as an emerging public action towards their environment. According to Lydon (2015), the act of tactical urbanism is a response towards formal planning that is characterised by a bottom up intervention. Although a city is a result of an accumulated formal planning, a city is also an unplanned form of entities that root from the flexible human activities in it (Silva, 2016). In responding the ever-changing development, people perform interventions and adaptation across the city (Silva, 2016).

In Jakarta alone, the flexibility and adaptivity is shown in public places across the city. Activities such as transaction, commuting, chatting, are all included in a bigger naration. These interventions happen in various scales, such as a pedestrian walks, within a residential area, or street corners.
Kampung is one of Jakarta's inseparable elements. This study finds that the act of tactical urbanism in Kampung Kerapu, North Jakarta generates a creation of sense of place in an area, based on the background of each tactical urbanism actions. How does the act of tactical urbanism by women and children occur in Kampung Kerapu? How do they affect the kampung's sense of place? The observation methods applied is emic approach and interviews with some the kampung residents. The descriptive methods are books, journals, and digital medias. The scope of this case study is limited to Kampung Kerapu, Jakarta Utara.

\section{LITERATURE REVIEW}

Sense of place is derived from the phrase spirit of place in which it etymologically comes from Latin language genius loci (Jackson, 1994, cited in Carmona et al., 2003). Jackson continues that it means in inhabiting a place, humans who are able to have a better experience than physical experience and senses, which integrates a sense of attachment to the place and elements in it are rooted in the spirit of place. If this matter is studied further, it means experience by Tuan (1977), where the place is as a spirit and humans contribute the senses (reason) in it. Similarly, the concept of spirit of place expressed by Steele (1981) that the spirit of place is the character of a place that creates a sense of place as a whole. Therefore, it can be concluded that the spirit of place is associated with the elements and characters that belong to the place, which in the end a place could stimulate people who are able to experience it through sensory experience to the feeling of attachment that arises.

The concept of sense of place has always been discussed about as one of the major issues in environmental psychology and architecture (Beidler and Morrison, 2015). Sense of place is derived from the concept spirit of place or genius loci (Jackson, 1994). According to Jackson (1994), when occupying a place, a man can have experiences beyond physical and sensual experience, which is feeling certain attachment to a place and the elements within that is referred to spirit of place. For Tuan (1977), a place without any hint of man in it is just mere geographic location. Thus, the meaning of place is closely related to the feeling of secure and attached, as opposed to the meaning of space (Tuan, 1977). 
When occupying a place, a person goes through a process of perception towards its environment. According to Steele (1981), perception is the process in which a man receives information from its surroundings, and thereupon immediately gives meanings based on the given information. In perceiving a place, Carmona et al. (2003) explains that sensation plays a big part initiating the process of perception. Carmona et al. continues that sensation is the result of collection from the four senses: sight, hearing, smell, and touch.

In relationship between human and place, setting is one essential component (Steele, 1981). According to Steele (1981), setting is a man's surroundings in specific time and location, which consists of physical and social factors. In this regard, Najafi et al. (2011) explains that both social and physical factors are interactional and affect each other. According to Shamai (1991), who conducted a study about measurement of the sense of place, there are three phases of the sense of place. The first is the ownership of a place, the second is the attachment to a place, and the last one is the commitment to a place (Shamai, 1991).

A place generates a certain quality, which is called the spirit of the place (Steele, 1981). The spirit of place has always been associated with a place's physical and social factors physical factors. Some of the physical factors include a place's geographic location, scale and proportion, geographic distinctiveness, and rich imagery (Steele, 1981). Regarding the quality of rich imagery, Lynch (1961)'s concept of imageability and mental map that consists of path, node, district, edge, and landmark as elements in the city contributes to a place's distinctiveness and imagery.

Besides physical factors, Steele (1981) explains several social factors that contribute to spirit of place. Those factors are effects on numbers of people, social climate, and characteristics of the people. Steele continued that a place can generate massively different spirit of place with numbers of people inhabiting a place. To illustrate, a jam-packed football stadium has entirely different spirit than when it is empty, in accordance to its core function, which is to accommodate a massive group of people.

Shamai (1991) conducted an empirical study to the measurement of sense of place. According to Shamai's (1991) study of various previous literatures regarding the sense of place, he concluded that the sense of place consists of three phases. The first phase is the sense of belonging to a place, the second is attachment to a place, and the highest is commitment to the place.

Lydon (2015) states that if the word "tactical" is associated with the city, tactical urbanism is a form of approach to develop the potential of a neighborhood through interventions that are low-cost, short-term, and flexible. Therefore, it can be concluded that tactical urbanism is an intervention that occurs in the city that has a specific purpose in response to the issues found.

If tactical urbanism is associated with the character of the city that always evolves, tactical urbanism is a movement that initiates a certain form of evolution that adapts to everchanging demand and condition of an environment (Silva, 2016). According to Finn (2014), the concept of 'tactical' in tactical urbanism has various advantages for its users, as it always complements what has been called as a long-term planning and urban planning strategies.

Tactical urbanism encourages the development of a city by using all creative potentials that is based on the social interactions of the people (Lydon, 2015). Silva (2016) supports the argument by stating that tactical urbanism gives a whole new perspective in urban planning.

With tactical urbanism's essence as an informal response within formal planning, it has been characterized as a bottomup intervention (Silva, 2016). Thus, it can be stated that the act of tactical urbanism emerged due to the initial formal policies that is no longer relevant to the people and their surroundings.

According to Lydon (2015), there are three types of tactical urbanism applications that are commonly carried out. First, tactical urbanism is initiated by the community as a form of breakthrough in delivering their aspirations. Their aspirations are conveyed by demonstrating various possibilities of change efforts towards the city (Lydon, 2015). Second, according to Lydon, tactical urbanism is an action initiated by the community in response to an issue of formal planning in the form of demonstrations acting as an instrument for the government, developers, and non-profit organizations to involve the community in planning the project that is or will be carried out. Third, tactical urbanism acts as an instrument to test a project before long-term investments are carried out (Lydon, 2015).

Lydon (2015) stated that the three applications of tactical urbanism above are not something that each stands exclusive from each other. The first point can act as a trigger for the latter to occur, and so on (Lydon, 2015). Both the community, government, and other formal institutions, all contribute in the tactical urbanism process (Lydon, 2015).

Lydon (2015) mentioned that tactical urbanism is one of the efforts in transforming a place that is residual or can be said to be less alive. In accordance to the means of tactics in tactical urbanism, it is expected that the resulting space increases the 'public' nature in the public space while still responding to the applicable context (Spataro, 2015).

Within its meanings, tactical urbanism can't be separated from the term DIY urbanism and other similar movements such as guerilla urbanism, pop-up urbanism, and insurgent urbanism (Finn, 2014). Tactical urbanism has become part of a greater narration about public spaces as well as the people's responsibility and rights toward them (Hou, 2012 cited in Finn, 2014). Inspite of the fact that the DIY urbanism movement consists of several other entities, every movement has one distinct character, that is as an action which arises from people's initiation.

\section{RESULT}

Kampung Kerapu is located in Penjaringan, North Jakarta. Kampung Kerapu is one of the three neighboring kampungs in one closely-packed neighborhood surrounding Tongkol street. The three kampungs are part of the 'Komunitas Anak Kali Ciliwung,' a community of settlements in the riverbank of the Ciliwung river.

In 2015, the government of DKI Jakarta planned to normalize the Ciliwung river. The attempt was to create an inspection road alongside the river banks as wide as 15 meters. 
However, by realizing the plan, it would mean that the Kampung Kerapu settlements would be demolished in order to accomplish the policy.

Despite the demolition news, the people of Kampung Kerapu and other neighboring kampungs Tongkol and Lodan were eager to stand for their kampungs (Munk, 2016). However, a negotiation then had been done with the government. An alternative emerged, in which the houses of Kampung Kerapu will be cut down 5 meters from the river bank to build the inspection road (Elyda, 2016). The residents were enthusiastic in the process of renovating their kampungs, and this behavior has shown as that even people of the kampungs has a good sense of teamwork in preserving Anak Kali Ciliwung (Tim Kampung Kerapu, 2017).

The utilization of public facilities, such as the streets of the kampung and the mushalla has played a major part in the kampung's everyday life. This area is especially used by women and children to accommodate their daily activities.

The three kampungs, Kerapu, Tongkol, and Lodan, embraces a historical value in it. Right behind Kampung Tongkol, lies a big historical wall that's surrounded by massive tree roots, standing strong since the Dutch colonial days (Budi, et al., 2018). Behind Kampung Kerapu is an old warehouse that is currently claimed by the DKI Jakarta government. According to Budi, et al. (2016), this old warehouse has long stood behind the three kampungs and contains historical value, seen from the neglectedness the building posseses.

\section{A. Kampung Kerapu and community spontaneous activities referring to tactical urbanism}

The atmosphere of Kampung Kerapu is crowded with the presence of children. Their playful activities have become a routine for the children of Kampung Kerapu. Towards the afternoon at 2:30 p.m., children's laughter can be heard on the front side of the Kampung Kerapu, precisely in front of the Kampung Kerapu Mushalla (prayer room).

In front of the mushalla, there were boys playing football while the girls were sitting on the edge of the mushalla. The crowd of children who played at that time had the age range from children who had not yet attended school to children who were in elementary school. Interaction between children at that time was very active and everyone recognized their friends, even their friend's age and family tree.

At 2:30 p.m. there were twelve children running around, but occasionally they returned to their house, going back toward their parents. When they return to the house, they interact briefly with their parents, only to simply talk or ask for snacks. Shortly after meeting their parents, they returned to their playground with their friends.

Their playful activities continued until 3:30 p.m when the call to prayer (adzan) echoed. Children who were in front of the mushalla immediately moved to the bench that was located away from the mushalla. This was done because of their awareness of the call to prayer and the coming of the residents to the mushalla to pray, which indeed happened at that moment. Children's awareness of activities with higher priority levels is reflected through the change of children's play spots at that time.
At 3:30 p.m., the children decided to move from the kampung to the warehouse next to their kampung to play football. According to Nabil, one of the kid from Kampung Kerapu, every afternoon they chose to continue playing football in the field that was located in the warehouse, this was caused by the limited size found on the streets of the Kampung Kerapu which incidentally only had a width of 5 meters.

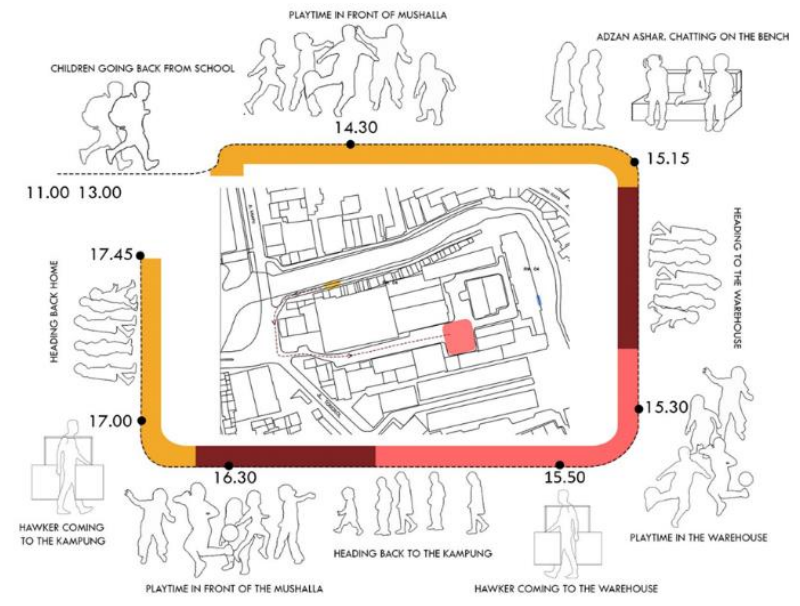

Figure 1 Mapping of the children's playtime activities

Source: Tim Pengabdian Masyarakat FTUI (2017), with personal alterations

The children rushed out of the kampung to the warehouse next to their kampung to play soccer, in which they need a bigger space. At the front, the warehouse is used as a parking lot for cars and trucks. However, when we walked along the trail to the back of the warehouse, we could see that the land is specifically used only as a parking lot for trucks and some cars.

To go to the space where the children play, they walk along the warehouse area about 150 meters from the warehouse gate. The form of the children's playground at that time was spacious. On that space, there were two goalposts made from bamboos. According to the children of Kampung Kerapu, they were the ones who put the goalposts on that land for their activity necessities.

In the overall playground activities of the Kampung Kerapu children, an intervention occurred. Interventions occur from within the Kampung Kerapu and into the land they used to play at. The issue that underlies this intervention is the need of playground for children to play, so that they get familiar around their physical environment, and used it as their own playground. Based on the theory of tactical urbanism, this initiation by children is a response towards formal urban planning.

Both the kampung where they lived and a warehouse built as part of the Kampung Kerapu area, these two were formal elements of a city design. In addition, looking at the needs of children to play and the unavailability of an integrated place that has a designation as a public place, the children created their own dialogue with their environment through their tactics to meet their needs, so there is intervention in the middle of kampung roads and warehouses, which basically don't have the main function as a public space. 
Previously, Lydon (2015) stated that a public place with minimal usage is one of the potential places for tactical urbanism intervention. In the phenomenon of children playing in Kampung Kerapu, children used the warehouse land that has long been vacant as a choice for their intervention. The old warehouse in the area of Kota Tua (Old City) is part of formal design. The presence of children playing on vacant land is a tactic given by children as an effort to revive the warehouse environment.

The next strategy that the children do is to place bamboo goalposts on the vacant land. The addition of goalposts by the children is one of the characteristics of tactical urbanism, in which the addition of elements or functions to the environment took place. Thus, children have become initiators in tactical urbanism interventions both with their presence and with the addition of functions and physical elements.

In children's playtime activities, they have their own timeline that ranges specifically in the afternoon. This time span is a temporary and non-permanent time span due to the specificity of the time of the intervention. According to Silva (2016), the tactical urbanism mechanism is a mechanism for interventions that have temporary and non-permanent periods. Therefore, it can be said that the activities of Kampung Kerapu children playing in the warehouse illustrate a temporary tactical urbanism effort.

In one unit of intervention, the crowd of children was followed by the presence of hawker vendors in the warehouse at 4:30 p.m. Fried food vendors came carrying a cart that contained skewered snacks in the form of kaki naga (dragon legs), nuggets, sausages, and sausage rolls wrapped in noodles. In accordance with figure 1, the seller then parked his cart, and soon the children came over to the seller to buy snacks.

At around 4:20 p.m., the children rushed back to the kampung. Arriving in the kampung, the children immediately prayed at the mushalla and returned to gather to play in front of the mushalla. At that time, three children returned home to pick up their roller skates to play. Thus, the activity of playing in front of the mushalla that afternoon continued with more variations, like playing football, playing roller skates, running around, and sitting and chatting.

Shortly afterwards, precisely at 4:30 p.m., the hawker vendors returned, this time to Kampung Kerapu. By the presence of vendors, the children again surrounded them to buy snacks. Tactical urbanism in this phenomenon is complemented by the presence of vendors as side actors in the running of tactical urbanism, with their efforts as entrepreneurs who approach consumers.

The activities of children in front of the mushalla include running, playing roller skates, and playing football but with less energy than when in the warehouse. This is caused by children's fear of their balls potentially falling into the river. In playing, their strategy is to play games that are linear and doesn't take up too much space.

\section{B. The creation of sense of place in tactical urbanism in Kampung Kerapu}

Upon entering the Kampung Kerapu, sensory experiences that include vision and hearing can be felt clearly, as Carmona et al. (2003) explained about the four senses as a support for the sense of place. The experience of the dominant sense of hearing is felt through shouts and laughter of small children playing in front of the mushalla.

The rich imagery in Kampung Kerapu is seen with a fairly consistent width of the house facade, which ranges from 2.5 meters to 3 meters. The uniformity of the house width gives a special character for Kampung Kerapu, so that the facade as a physical element becomes a relatively distinct element.

The width of the road from the building facade in Kampung Kerapu to the edge of the river is about 5 meters wide, but of course the amount is then reduced by the presence of the residents' items placed on the edge of the river. Laying furniture on the riverside almost fills along the way of Kampung Kerapu, so the width of the street as a path destined for circulation is certainly reduced. However, this actually affects the creation of a sense of place and its correlation with scale and proportion
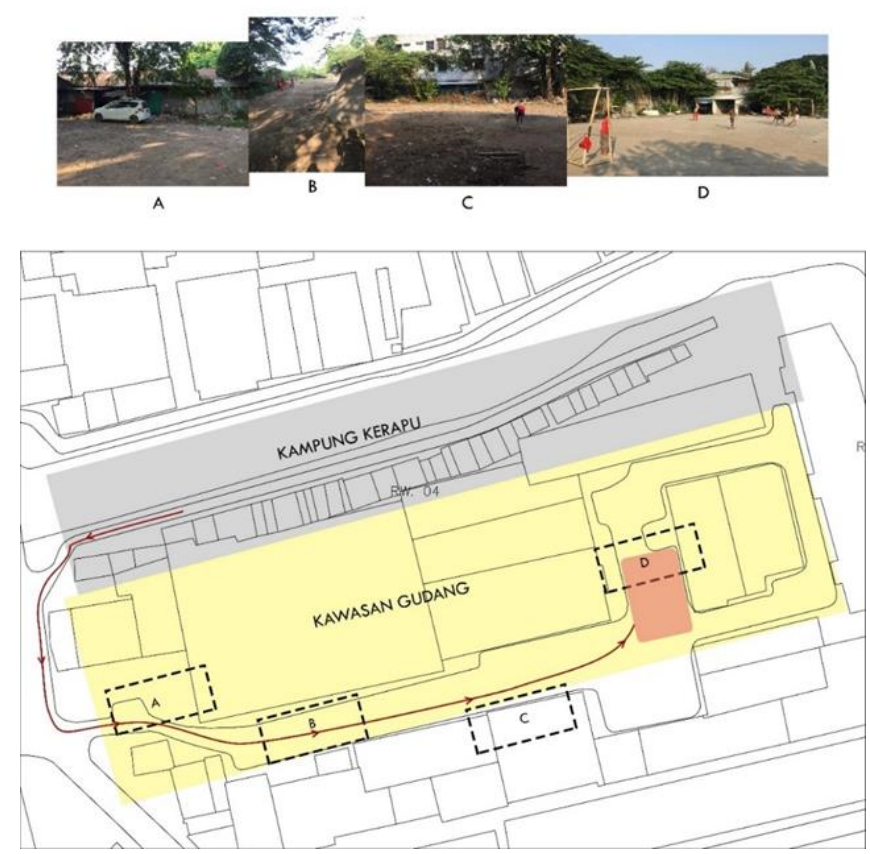

Figure 2 The route from Jalan Tongkol to the vacant warehouse

Source: Tim Pengabdian Masyarakat FTUI (2017), with personal alterations

The width of the road that is quite narrow and the placement of seats across the front of the residents' houses creates an intimate atmosphere along the way of Kampung Kerapu. Intimacy that is created then supports the high interaction between people; such as between the women, fellow children, and between women and children. In addition, by placing the seat opposite the house, residents can easily spend time with their neighbors across the house without having to worry about the security issues of their house. This can be seen with the atmosphere of the street which is quite active by the presence of Kampung Kerapu mothers who talk and spend their time throughout the afternoon on the seat opposite the house.

While the women spent their time across the house, children chose mushalla as their playground. The choice of place can be correlated with the location of the mushalla, in 
accordance to its positioned in the mental map. Examined by the width of the building, the mushalla has the longest width among other buildings. In addition, the mushalla is also the only public facility in the kampung. This certainly makes the image of the mushalla as a landmark in the kampung because of its contrasting function with the residents' settlements.

In addition, the selection of mushalla can also be reviewed from the children's awareness of their numbers. During the afternoon, there were thirteen children playing in the kampung. In accordance to the environmental conditions, of course the children will choose a wider space that have less furniture along the streets. For this reason, the children quickly chose the street in front of the mushalla as their playground.

The generated sefnse of place is created through the way children perceive the kampung and the streets in it. By getting information about the width of the road, and the geographical elements of the kampung, the children are then informed of their space needs in playing. After gaining awareness of their own needs, they interpreted the environment with activities that they could do in front of the mushalla in accordance with the activities they needed in the afternoon, which is playing. Thus, the sense of place in front of the mushalla and in the whole kampung is created through the activities and the high number of children in the narrow road width.

The warehouse is surrounded by old buildings around it. The site's geographical distinctiveness can be sensed form the dry lands of the place. The vacant old buildings give out a sign of neglectedness which can be felt along during the experience. Before the children came, the warehouse land was empty and there were only a few truck drivers hanging out. In addition, the movement of truck drivers was also not dominant and it stayed static, in which they chatted with their fellow friends. In this matter, the sense of place can be said to be less powerful. Seen from a bigger picture as a whole area of the three kampungs, the vacant land does not act as a landmar. It has no distinctive features that can be seen from around the area. The warehouse had been empty and now acts as a parking area for trucks and cars.

\section{The sense of place through tactical urbanism}

In terms of cognitive and perception factors, the children have percepted their physical environment and altered it according to their shared motivation, which is to play with their friends. Based on Gehl's (2011) theory, the children's activitiy is categorized as an optional activity due to its level or urgency in everyday life. This case has shown that the tactical action of the children is fostered by the availability of proper public spaces.

Initially, Kampung Kerapu has distinct sense of place which has already been contributed by its intimate atmosphere and identical façade. Subsequently, the women and children contributed to the liveliness of the kampung with their own tactical activities which altered some original elements of their living place. The existence of children in the intervention marks as the creation of a whole different sense of place in terms of the increasing number of crowds. Moreover, the age range of the children as actors, which extends from as low as 3 years old to 12 years old has become a consistent social climate in the phenomenon.

The children that play football subsequently becomes the doers inside the warehouse, while the truck drivers have become the watchers. The intervention boundary was shown by the zoning of the kids in percepting the mere vacant land into a place, a defined one, for their playing needs. The children firstly initiated their tactics by searching for their playtime activities. In the meantime, the discovery lead to the act of addition in tactical urbanism. In the creation of sense of place, the residents of the people of Kampung Kerapu has high attachment to a place due to their frequency of activities, in this phenomenon, by both the women and children.

\section{CONCLUSION}

The act of tactical urbanism in Kampung Kerapu has specific actors and their own underlying issues. First of all, certain spaces was specially occupied by certain group of people, in this case, the women and children and Kampung Kerapu. This space occupancy is indeed an act of tactical urbanism. The need of the women to gather with their fellow community of women insisted the action. The same situation goes to the children, in which the need of a bigger playtime activities space has insisted the act of tactical urbanism, by using a residual place.

The narrow streets have become a communal space especially for the women and children. In accordance to the people's outdoor activities, the need of optional activities has pushed the woman to gather around and make their residential area's circulation an unlikely communal space. With two different age range, the need of optional activities has initiated the act of tactical urbanism, in terms of adding some elements to their build environment and altering their original means of function. The change of function of a space and perception process in which a space becomes a more meaningful place, are the characters of tactical urbanism in Kampung Kerapu.

\section{ACKNOWLEDGMENT}

This paper is a part of undergraduate thesis funded by PITTA (Publikasi Internasional Terindeks untuk Tugas Akhir) Grant 2018. Authors thank all the women and children of Kampung Kerapu that have provided informations needed in the data collection.

\section{REFERENCES}

[1] Beidler, K., \& Morrison, J. (2015). Sense of place: inquiry and application. Journal of Urbanism: International Research On Placemaking And Urban Sustainability, 9(3), 205-215.

[2] Budi, T., Fatimah, T., Irawati, M., Padawangi, R. (2016). Vernacular City Kota Tua: Cultural Identity in Everyday Urban Heritage.

[3] Carmona, M. et al. (2003). Public Places, Urban Spaces. Oxford: Architectural Press

[4] Gehl, J. (2011). Life between buildings. Washington, DC: Island Press.

[5] Hou, J. (2010). (Not) Your Everyday Public Space. Insurgent Public Space: Guerrilla Urbanism and the Remaking of Contemporary Cities, edited by Jeffery Hou, 1-17. Oxford: Routledge.

[6] Lydon, M., Garcia, A., \& Duany, A. (2015). Tactical Urbanism: Short Term Action for Long Term Change. Island Press.

[7] Lynch, K. (1960). Image of The City. MIT Press.

[8] Munk, D. (2016). Jakarta's eco future? River community goes green to fight eviction threat. Retrieved from https://www.theguardian.com/cities/2016/nov/25/jakarta-kampungtongkol-eco-future-river-community--green-to-fight-eviction-threat

[9] Shamai, S. (1991). Sense of Place: An Empirical Measurement. Geoforum, 22(3), 347-358. 
[10] Silva, P. (2016). Tactical Urbanism: Towards an Evolutionary Cities' Approach?. Environment And Planning B: Planning And Design, 43(6), 1040-1051.

[11] Spataro, D. (2015). Against a de-politicized DIY urbanism: Food Not Bombs and the struggle over public space. Journal Of Urbanism: International Research On Placemaking And Urban Sustainability, 9(2), 185-201.
[12] Steele, F. (1981). The Sense of Place. Boston: CBI Publishing Company.

[13] Tuan, Y. (1977). Space and Place: The Perspective of Experience. Minneapolis: University of Minnesota Press. 